A TEXTBOOK ON ALGAE 
Macmillan International College Editions (MICE) will bring to university, college, professional and school students in developing countries low cost but authoritative books covering the history and cultures of the Third World, and the special aspects of its scientific, technical, social and economic development. In other parts of the world MICE will satisfy the growing demand for information about the developing countries.

The MICE programme contains many distinguished series in a wide range of disciplines, some titles being regionally biassed, others being more international. Library editions will usually be published simultaneously with low cost paperback editions.

For full details of the MICE list, please contact the publishers.

Macmillan Tropical Biology Series

This is a new series of textbooks for undergraduate biology students in the tropics. 


\section{A TEXTBOOK ON ALGAE}

H D Kumar and H N Singh

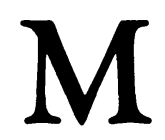


(C) Affiliated East-West Press Private Limited

Softcover reprint of the hardcover 1st edition 1979 978-0-333-31541-5

All rights reserved. No part of this publication may be reproduced or transmitted, in any form or by any means, without permission.

First Indian edition published by Affiliated East-West Press Private Limited 1971 Second Indian edition 1976

First Macmillan International College Edition (taken from second Indian edition) 1979

This edition is published by

THE MACMILLAN PRESS LTD

London and Basingstoke

Associated companies in Delhi Dublin

Hong Kong Johannesburg Lagos Melbourne

New York Singapore and Tokyo

\section{British Library Cataloguing in Publication Data}

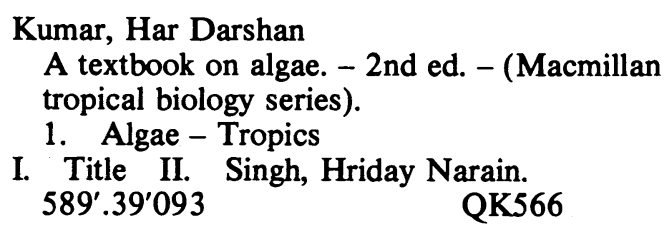

ISBN 978-0-333-26072-2

ISBN 978-1-349-16144-7 (eBook)

DOI 10.1007/978-1-349-16144-7

This book is not for sale in India, Sri Lanka, Pakistan and Bangladesh.

This book is sold subject to the standard conditions of the Net Book Agreement.

The paperback edition of this book is sold subject to the condition that it shall not, by way of trade or otherwise, be lent, resold, hired out, or otherwise circulated without the publisher's prior consent in any form of binding or cover other than that in which it is published and without a similar-condition including this condition being imposed on the subsequent purchaser. 
Foreword by G. E. Fogg vi

Preface vii

\section{Part I COMPARATIVE ACCOUNT OF ALGAE}

1 Introduction 3

2 Comparative Morphology 11

3 Reproduction and Perennation 26

4 Economic Importance 38

Part II STRUCTURE AND REPRODUCTION OF SELECTED ALGAE

5 Cyanophyta 51

6 Chlorophyta $\quad 69$

7 Xanthophyta 123

8 Bacillariophyta 131

9 Phaeophyta 141

10 Rhodophyta 161

11 Field and Laboratory Techniques 178

Suggestions for Further Reading 203

Glossary 206

Index $\quad 212$ 


\section{Foreword}

The study of algae is a rapidly expanding branch of botanical science. Some of these simple plants are being used as experimental material for advanced research in biochemistry, genetics and molecular biology; others are of great economic importance both as nuisances and as contributors to the productivity of soils and fisheries. Beyond this, most algae are extremely beautiful objects in themselves and perhaps in the ultimate analysis this is the main source of their attraction for scientists. Nevertheless, however good the reasons for studying the algae, they may be nullified if the student is faced with inadequate, uninspiring or intimidating textbooks. I am therefore very glad that two such active and distinguished Indian workers on algae as Professor H. D. Kumar and Dr. H. N. Singh have found time to write this introductory text. By providing a clear and sound background of the morphology which every student of the algae requires but at the same time indicating the other aspects and showing how one may begin practical work on the algae oneself, I believe that they have produced a book which will contribute greatly to the future development of the subject.

G. E. Fogg, Sc.D., F.R.S.

The Marine Science Laboratories (Menai Bridge) University College of North Wales, Bangor 


\section{Preface}

The need for a suitable textbook on algae for undergraduates has been felt in many universities in recent years. Our main objective in writing this book is to fulfil this need and to present an updated account of morphology and reproduction of the more important genera, supplemented with brief descriptions of recent contributions on their physiology, biochemistry, cytology and genetics.

Any attempt at improving the standard of teaching of algae must begin in practical classes and field studies. One complete chapter is therefore exclusively devoted to field and laboratory techniques. It includes some of the simpler methods for culturing, microchemical study, separation of pigments by chromatographic techniques, preparation of herbarium sheets and permanent slides, estimation of growth and primary productivity, and ecological study of soil and freshwater forms.

The remaining chapters incorporate brief and simple accounts of some important and representative types. The discussion also covers topics of current interest such as the concept of Procaryota and Eucaryota; the ultrastructure of algal cells and their organelles; the developmental cycle and genetic recombination in certain blue-green algae; the physiology and biochemistry of nitrogen fixation and heterocyst differentiation; the nature of sexual substances (gamones) produced by algae; genetics in Chlamydomonas; and the physiology of growth and differentiation in synchronous cultures of Chlorella. The genera described in Part II are those usually prescribed for undergraduates. Minute variations in structure, reproduction and life history have been avoided so as to give proportionately greater coverage to micromorphology and modern experimental studies. It is hoped that the general comparative topics dealt with in Part I will be equally useful for advanced study.

Test questions and selected references for further reading are incorporated at appropriate places. Exhaustive lists of references have been avoided but care has been taken to include the latest references as far as possible, since the reader can always find most of the earlier works of individual authors in the citations given.

We are greatly indebted to Professor G. E. Fogg for many valuable suggestions and for critically reviewing the manuscript. We thank Professors R. N. Singh, T. V. Desikachary, H. A. Von Stotsch, M. B. E. Godward, B. M. Johri, Drs. V. P. Singh and F. E. Round for their helpful comments. We are grateful to Dr. Norma J. Lang of the University of California, Davis, for providing the electron micrograph of Anabaenopsis circularis (frontispiece).

Varanasi

H. D. Kumar

H. N. Singh 